Article

\title{
Dynamic Models for Exploring the Resilience in Territorial Scenarios
}

\author{
Vanessa Assumma ${ }^{1, *(\mathbb{D}}$, Marta Bottero ${ }^{1}{ }^{\mathbb{D}}$, Giulia Datola ${ }^{1}{ }^{1}$, Elena De Angelis ${ }^{1}$ and \\ Roberto Monaco $^{2}$ \\ 1 Interuniversity Department of Regional and Urban Studies and Planning, Politecnico di Torino, 10129 Torino, \\ Italy; marta.bottero@polito.it (M.B.); giulia.datola@polito.it (G.D.); elena.deangelis@polito.it (E.D.A.) \\ 2 Former Full Professor, Politecnico di Torino, 10129 Torino, Italy; roberto.monaco@formerfaculty.polito.it \\ * Correspondence: vanessa.assumma@polito.it
}

Received: 16 October 2019; Accepted: 4 December 2019; Published: 18 December 2019

\begin{abstract}
The present paper focuses on the role covered by dynamic models as support for the decision-making process in the evaluation of policies and actions for increasing the resilience of cities and territories. In recent decades, urban resilience has been recognized as a dynamic and multidimensional phenomenon that characterizes urban and metropolitan area dynamics. Therefore, it may be considered a fundamental aspect of urban and territorial planning. The employment of quantitative methods, such as dynamic models, is useful for the prediction of the dynamic behavior of territories and of their resilience. The present work discusses the system dynamics model and the Lotka-Volterra cooperative systems and shows how these models can aid technicians in resilience assessment and also decision makers in the definition of policies and actions, especially if integrated in wide evaluation frameworks for urban resilience achievements. This paper aims to provide an epistemological perspective of the application of dynamic models in resilience assessment, underlying the possible contribution to this issue through the analysis of a real case study and methodological framework. The main objective of this work is to lay the basis for future compared applications of these two models to the same case study.
\end{abstract}

Keywords: urban resilience; dynamic models; decision making; scenario planning

\section{Introduction}

Cities and territories across the world are increasingly exposed to a number of risks, hazards and stresses [1,2]. These affect all urban system dimensions, from the environmental to the social and economic [3,4]. Therefore, the concept of resilience is increasingly being used in urban and territorial policy in order to prepare urban systems for hazards and uncertainties [2,5,6]. Urban resilience is defined as a dynamic and multidimensional phenomenon that characterizes metropolitan areas as complex systems at all scale dimensions [7-9]. Urban resilience is related to several disciplines and domains, such as risk reduction, climate change and adaptation strategy. More recently, urban resilience has also been involved in the definition of policies and actions for achieving urban and territorial purposes $[2,7,9]$. The guidelines for increasing urban resilience are effective planning procedures-the identification and prioritization of which require the involvement of experts with specific competences and from different disciplines in the decision-making process [10]. This paper explores the role of dynamic models in support of the definition of policies and actions to enhance urban resilience. These models belong to the family of mathematical modelling, which is able to simulate the behavior of complex systems over time by using a set of Ordinary Differential Equations (ODEs). In this paper, dynamic models are investigated according to methodological background and operative characteristics. The main aim is to consider their general characteristics and peculiarities 
in order to underline dynamic model (DM) features that are closely related to the decision-making process in territorial and urban planning [11]. DMs are recognized as suitable tools to evaluate policies and actions aimed at increasing urban resilience [12-14]. This property is related to the fact that these models are built and grounded on dimensions related to both urban systems and urban resilience. In fact, during the construction of the model, it is necessary to select and identify which aspects of a territorial system have to be included with reference to the evaluation goal, from the environmental to the economic dimension $[11,12,15]$. In this sense, DMs are able to reveal both the dynamic behavior of urban and territorial systems and the impacts of policies on the key variables identified.

Specifically, the main aim of this work is to study the principal characteristics of the system dynamics model (SDM) and Lotka-Volterra models (LV) in order to apply both to the same case study. The final purpose of this investigation is to understand the importance of the modelling approach in the field of resilience evaluation.

The paper is structured as follows: Section 2 describes the current state of the art of resilience and urban resilience; Section 3 explains the role of dynamic models-the system dynamic models (SDM) and Lotka-Volterra models (LV) - in the decision-making process and summarizes their methodological background, state of art and some illustrative examples; Section 4 explains how the SDM models and LV models could contribute to urban planning; a comparative matrix is developed to investigate the utility of the considered models in predicting support in the design of future transformation scenarios; and Section 5 includes some final remarks and future perspectives.

\section{State of Art of Resilience and Urban Resilience}

The concept of resilience is used in a wide range of disciplines and domains such as psychology [16,17], ecology [18], engineering [19,20], socio-ecological systems [21-23], climate change and adaptation [24-26], urban planning [27,28] and disaster risk management [9,29-32]. Furthermore, in the last two decades, resilience has become an important goal for cities that are often theorized as highly complex with an adaptive system [32-34].

The term "resilience" came from the Latin word resilio, which literally means "to bounce back" [35]. However, its origins, meanings and interpretations are quite ambiguous [36,37].

Table 1 summarizes some of the most representative definitions of resilience in different disciplines. It reveals that engineering, ecological and socio-ecological resilience are the most used definitions in literature [38]. Furthermore, this table makes clear the division between the dynamic and the static interpretation of resilience [32].

The static interpretation refers to the engineering definition [9], whereas the dynamic interpretation is related to the socio-ecological perspective [18]. Engineering resilience should be understood as the measure of the speed with which the system can return to its previous equilibrium. Therefore, the engineering perspective does not consider the transformation [32]. On the other hand, the socio-ecological perspective is grounded on the assumption that a return to the previous equilibrium may be not possible in complex ecosystems [32,39]. Socio-ecological resilience refers to the capacity of the system to transform itself, thus returning to a previous equilibrium.

This recognition is fundamental to understand which perspective may be adopted to analyze an urban system, in order to concern about urban resilience with the correct background.

At the beginning, it was particularly referred to climate change $[40,41]$. Subsequently, in the latest studies $[7,9,42]$ it has also been related to stresses and hazards which effect the different dimensions of an urban system [33]. From a careful literature review, what emerges clearly about urban resilience are these highlights: (1) The most important study of resilience applied on urban systems is Holling's studies which referred to socio-ecologic resilience [43]; (2) Urban resilience is defined as a complex and multi-dimensional phenomenon [9]; (3) Urban resilience is not a static condition, but it is a dynamic process in spatial and temporal scales [8]; (4) There is not a unique definition [32]; and (5) Urban resilience has recognized an increase in literature, in academic studies, political studies, social debate and urban planning $[9,30,36,44-46]$. 
Table 1. Representative resilience definition by different fields (Elaboration from Meerow, 2016 and Bharma et al., 2011).

\begin{tabular}{|c|c|c|c|}
\hline Author & Field & Definition of Resilience & $\begin{array}{l}\text { Static or } \\
\text { Dynamic }\end{array}$ \\
\hline Holling, 1973 & Ecology & $\begin{array}{l}\text { "The ability of these systems to absorb changes of states variables, driving } \\
\text { variables, and parameters, and still persist" (p. 17). }\end{array}$ & Dynamic \\
\hline Pimm, 1984 & Ecology & $\begin{array}{l}\text { "How fast the variables return towards their equilibrium following a } \\
\text { perturbation" (p. 322). }\end{array}$ & Static \\
\hline $\begin{array}{l}\text { Carpenter et al., } \\
\quad 2001\end{array}$ & $\begin{array}{l}\text { Social-ecological } \\
\text { systems }\end{array}$ & $\begin{array}{l}\text { "The magnitude of disturbance that can be tolerated before a socioecological } \\
\text { system (SES) moves to a different region of state space controlled by a different } \\
\text { set of processes" (p. 765). }\end{array}$ & Dynamic \\
\hline Adger, 2000 & Geography & $\begin{array}{l}\text { "The ability of groups or communities to cope with external stresses and } \\
\text { disturbances as a result of social, political and environmental change" (p. 347). }\end{array}$ & Dynamic \\
\hline Rose, 2007 & Economics & $\begin{array}{l}\text { "The speed at which an entity or system recovers from a severe shock to } \\
\text { achieve a desired state" (p. 384). }\end{array}$ & Dynamic \\
\hline Fiksel, 2006 & $\begin{array}{c}\text { Systems } \\
\text { engineering }\end{array}$ & $\begin{array}{l}\text { "The capacity of a system to tolerate disturbances while retaining its structure } \\
\text { and function" (p. 16). }\end{array}$ & Dynamic \\
\hline $\begin{array}{l}\text { Zhu and Ruth, } \\
2013\end{array}$ & $\begin{array}{l}\text { Industrial } \\
\text { ecology }\end{array}$ & $\begin{array}{l}\text { "The ability [for industrial ecosystems] to maintain their defining feature of } \\
\text { eco-efficient material and energy flows under disruptions" (p. 74). }\end{array}$ & Dynamic \\
\hline $\begin{array}{c}\text { Zeng and } \\
\text { colleagues, } 2013\end{array}$ & Networks & $\begin{array}{l}\text { "The critical threshold at which a phase transition occurs from normal state to } \\
\text { collapse" (p. 12). }\end{array}$ & Static \\
\hline Ouyang, 2014 & Engineering & $\begin{array}{l}\text { "The joint ability of a system to resist (prevent and withstand) any possible } \\
\text { hazards, absorb the initial damage, and recover to normal operation" (p. 53). }\end{array}$ & Static \\
\hline Adger, 2000 & Social resilience & $\begin{array}{l}\text { "Ability of groups or communities to cope with external stresses and } \\
\text { disturbances as a result of social, political and environmental change" (p. 347). }\end{array}$ & Static \\
\hline
\end{tabular}

From these aspects, this paper aims to focus on the definition of urban resilience to highlight the communalities and differences in academic and policy debate. The objective of this analysis is to highlight the malleability of the urban resilience concept and to stress on its implications in policy definition [47]. Table 2 lists a series of definitions on urban resilience by considering academic and political references with the purpose to better understand what the needs and the tools are to be employed as support of the decision-making process for building resilient cities.

Table 2. Some peculiar definitions of Urban Resilience (Authors' elaboration, 2019).

\begin{tabular}{|c|c|c|}
\hline Authors and Year & Definition & Field \\
\hline Meerow et al., 2016 & $\begin{array}{l}\text { "Urban resilience refers to the ability of an urban system-and all its constituent socio-ecological } \\
\text { and socio-technical networks across temporal and spatial scales-to maintain or rapidly return to } \\
\text { desired functions in the face of a disturbance, to adapt to change, and to quickly transform } \\
\text { systems that limit current or future adaptive capacity" (p. 39). }\end{array}$ & Academic \\
\hline $\begin{array}{l}100 \text { Resilient City } \\
\text { Campaign, } 2013\end{array}$ & $\begin{array}{l}\text { "Urban resilience is the capacity of individuals, communities, institutions, businesses, and } \\
\text { systems within a city to survive, adapt, and grow no matter what kinds of chronic stresses and } \\
\text { acute shocks they experience" (p. 10). }\end{array}$ & Political \\
\hline Urbact, 2004 & $\begin{array}{l}\text { "Urban resilience is the capacity of urban systems, communities, individuals, organisations and } \\
\text { businesses to recover, maintain their function and thrive in the aftermath of a shock or a stress, } \\
\text { regardless its impact, frequency or magnitude" (p. 6). }\end{array}$ & Political \\
\hline Lu and Stead, 2013 & $\begin{array}{l}\text { "Urban resilience is the ability of a city to absorb disturbance while maintaining its functions and } \\
\text { structures" (p. 200). }\end{array}$ & Academic \\
\hline $\begin{array}{l}\text { Thornbush et al., } \\
2013\end{array}$ & $\begin{array}{l}\text { "Urban resilience is a general quality of the city's social, economic, and natural systems to be } \\
\text { sufficiently future-proof" (p. 2). }\end{array}$ & Academic \\
\hline Leichenko, 2011 & "Urban resilience is the ability to withstand a wide array of shocks and stresses" (p. 164). & Academic \\
\hline
\end{tabular}


Table 2. Cont.

\begin{tabular}{|c|c|c|}
\hline Authors and Year & Definition & Field \\
\hline ICLEI, 2015 & $\begin{array}{l}\text { "A resilient city is prepared to absorb and recover from any shocks or stress while maintaining its } \\
\text { essential functions, structures and identity as well as adapting and thriving in the face of } \\
\text { continual change. Building resilience requires identifying and assessing hazard risks, reducing } \\
\text { vulnerability and exposure, and lastly, increasing resistance, adaptive capacity and emergency } \\
\text { preparedness!" (p. 1). }\end{array}$ & Political \\
\hline $\begin{array}{l}\text { Urban Resilience } \\
\text { HUB, } 2015\end{array}$ & $\begin{array}{l}\text { "The measurable ability of any urban system, with its inhabitants, to maintain continuity through } \\
\text { all shocks and stresses, while positively adapting and transforming toward sustainability" (p. 6). }\end{array}$ & Political \\
\hline UNISDR, 2015 & $\begin{array}{l}\text { "The ability of a system, community or society exposed to hazards, to resist, absorb, } \\
\text { accommodate, adapt to, transform and recover from its effects in a timely and efficient manner, } \\
\text { including through the preservation and restoration of its essential basic structures and functions } \\
\text { through risk management" (p. 3). }\end{array}$ & Political \\
\hline
\end{tabular}

These different definitions are listed to underline their communalities and differences in their meaning. They are different from the formal point of view. However, all these definitions concern with the multidimensional and transformative approach of urban resilience [7]. They also focus the attention on the dynamic behavior of resilience processes both in spatial and time scales [6].

This means that building urban resilience requires looking at urban and territorial systems holistically. It is necessary to understand cities in all dimensions and identify interdependencies and risks they may face.

For this application, the definition of Meerow et al. [32] has been considered for its holistical view of urban systems and its attention to both spatial and temporal scales.

Nowadays, the main problems which regard the design of policies and strategies to build urban resilience lies in the difficulty of evaluating this process over time and in spatial dimensions.

This paper explores the DMs in order to verify their efficiency in application in scenario planning, in order to find suitable tools which may support decision makers to define and prioritize strategies and policies to enhance urban resilience.

\section{Dynamic Models in the Decision-Making Process}

The definition of effective policies needs to be informed by a holistic understanding of the system processes. Their complex interactions and the ways they respond to various changes and inputs have to be evaluated. In this sense, models are, in general, seen as useful tools to aid actors and stakeholders to analyze alternative possible solutions and assess their outcomes. In fact, models generally integrate knowledge developed across a broad range of fields. They are generally used for different purposes. In this section, we focus on their application in management and treatment of uncertainty. Dynamic models cover a number of different methods and approaches able to simulate the behavior of future scenarios. Among the different methods belonging to the family of mathematical modelling, the present paper considers the system dynamics model (SDM) and the Lotka-Volterra model (LV). In this section, the methodological background and the state of art are investigated for both the SDM and LV models with the aim to highlight their fundamental role in the prediction of 
possible future scenarios for exploring urban resilience. Moreover, an illustration of some relevant applications is proposed in order to explain the methodological steps for the applications and the type of results that can be obtained.

\subsection{Urban Simulation Models}

In this paragraph, an overview of the urban simulation methods is given. The selected urban simulation methods are here discussed as reliable support in the decision-making process, especially in the case of designing urban and territorial transformations that may solicitate perturbations on the system on its resilience. Starting from a literature review [48], different simulation models have been selected to be analyzed. Table 3 lists the considered models and describes them, considering field and purpose of applications, types of data, treatment of space, time and uncertainty.

Table 3. Overview of urban simulation models (Authors' elaboration from Kelly et al., 2013).

\begin{tabular}{|c|c|c|c|c|c|}
\hline Model & Field of Application & Types of Data & $\begin{array}{c}\text { Treatment of } \\
\text { Space }\end{array}$ & $\begin{array}{l}\text { Treatment of } \\
\text { Time }\end{array}$ & Uncertainty \\
\hline $\begin{array}{l}\text { Bayesian } \\
\text { networks }\end{array}$ & $\begin{array}{l}\text { Decision-making and } \\
\text { management, Social learning, } \\
\text { System understanding, } \\
\text { Prediction }\end{array}$ & $\begin{array}{l}\text { Qualitative and } \\
\text { quantitative }\end{array}$ & Non-spatial & Non-temporal & $\begin{array}{l}\text { Structural learning } \\
\text { from data and } \\
\text { knowledge is possible }\end{array}$ \\
\hline $\begin{array}{l}\text { Coupled } \\
\text { component } \\
\text { models }\end{array}$ & $\begin{array}{l}\text { Prediction, Forecasting, System } \\
\text { understanding, Decision- } \\
\text { making and management }\end{array}$ & $\begin{array}{l}\text { Mainly quantitative } \\
\text { but qualitative are } \\
\text { possible }\end{array}$ & $\begin{array}{l}\text { Comprehensive } \\
\text { set of options }\end{array}$ & Routine & $\begin{array}{l}\text { Comprehensive } \\
\text { discrimination tests } \\
\text { between alternatives }\end{array}$ \\
\hline $\begin{array}{l}\text { Agent-based } \\
\text { models }\end{array}$ & $\begin{array}{l}\text { Social learning, System } \\
\text { understanding }\end{array}$ & Mainly quantitative & Limited & Limited & $\begin{array}{l}\text { Comprehensive } \\
\text { discrimination tests } \\
\text { between alternatives }\end{array}$ \\
\hline $\begin{array}{l}\text { Knowledge- } \\
\text { based } \\
\text { models }\end{array}$ & $\begin{array}{l}\text { Decision-making and } \\
\text { management, Prediction, } \\
\text { Forecasting }\end{array}$ & $\begin{array}{l}\text { Qualitative and } \\
\text { quantitative }\end{array}$ & Non-spatial & $\begin{array}{l}\text { Usually non- } \\
\text { temporal }\end{array}$ & $\begin{array}{l}\text { Comprehensive } \\
\text { discrimination tests } \\
\text { between alternatives }\end{array}$ \\
\hline
\end{tabular}

This overview of different models has been useful to support the choice of the model to experiment and use in investigating the urban resilience.

\subsection{System Dynamics Model}

\subsubsection{Methodological Background and State of Art}

System dynamics model (SDM) is an operative approach for helping reveal temporal behavior of complex systems considering their non-linearity, time-delay and multi-loop structure [49,50]. SDM is based on the System Dynamics approach which was introduced by Forrester [51,52] for investigating the feedback information of industrial systems and improving the organizational form [53]. SDM is an effective tool for modelling intersectional dynamics, such as the prey-predator models [54,55]. The relationships and interactions between variables in the system are analyzed by this tool (SDM) in order to simulate its dynamic evolutions in terms of processes, information and organizational boundaries [50].

In SDM, complex and dynamic systems are described both in qualitative/conceptual and quantitative representations. The qualitative modelling is performed by the causal loop diagram (Figure 1). This tool is used to graphically represent the feedback loops structure of the system. Causal loop diagram (Figure 1) describes the basic mechanism of the system, in order to represent the causes of its dynamics behavior over time $[50,56]$. The relationships between the variables can be either positive or negative, as shown in Figure 1. A positive relationship signifies that variables change equally. By contrast, a negative relationship means that the variables change inversely.

Quantitative modelling is represented by stock and flow diagram (Figure 2). Stock is the first basic building block in SDM and it represents the variable which describes the condition of the system at any particular time [12,50,57-59]. Flow is the second block in SDM and it tells how stocks change over time. 


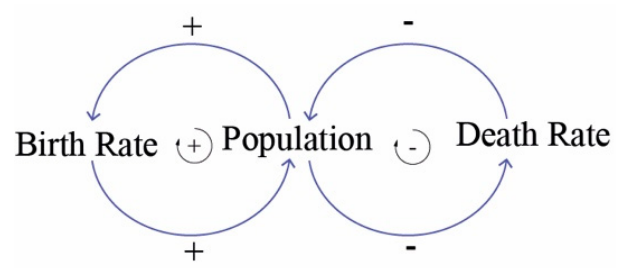

Figure 1. Causal loop diagram (Tan et al., 2018).

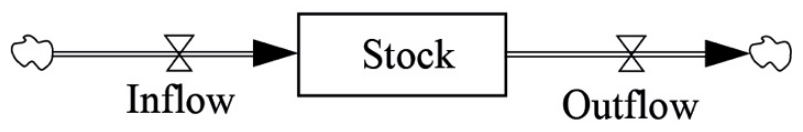

Figure 2. Stock and flow diagram (Source: Authors elaboration).

From a mathematical point of view, stock and flow diagrams are represented by first-order finite difference equations. These allow to simulate the dynamic behavior of the system. The differential equations which characterize stock and flow can be expressed as:

$$
\operatorname{tock}(t)=\operatorname{stock}(t 0)+\int_{t 0}^{t}(\text { inflow }(t)-\text { outflow }(t)) d t
$$

and this integration equation in the differential equation form is:

$$
\frac{d(\text { Stock })}{d t}=\operatorname{inflow}(t)-\operatorname{outflow}(t) .
$$

The most frequent type of possible system behavior can be summarized as follows [60]:

- Exponential growth or decline, which is characterized by only positive or only negative feedbacks;

- Goal-seeking behavior, which is created by first-order negative feedback;

- S-shaped growth. This behavior, over time, is created by a combination of positive and negative feedback loops. In this case, both loops struggle for dominance until the struggle ends with a long-term equilibrium;

- Oscillations. This is one of the most common types of dynamic behaviors in the world and it can have different forms, such as (1) sustained oscillations; (2) damped oscillations; (3) exploded oscillations; (4) chaos. The structure that creates oscillations is a combination of negative feedback loops and delay.

Currently, SDMs are used to support policy design and management for sustainable development in those fields characterized by a high level of uncertainty, such as transport management $[58,61,62]$, land use [63], waste management [59] and also sustainable urban development [13,57,64,65]. In the last few decades, an increase of SDM application has been observed in literature [66], especially in the urban development field. Table 4 lists some of the prevalent SDM applications with particular attention to urban system and urban development.

Table 4 shows that SDM is an effective tool for supporting the evaluation of different development scenarios' performance, considering their possible effects over time. For this reason, it is considered as a useful tool to support decision makers in setting policies. 
Table 4. Example of recent applications of System Dynamics Model in urban planning (Authors' elaboration, 2019).

\begin{tabular}{ccll}
\hline $\begin{array}{c}\text { Authors and } \\
\text { Year }\end{array}$ & Territorial Scale & \multicolumn{1}{c}{ Method } & Outcome \\
\hline Wu et al., 2018 & $\begin{array}{c}\text { Metropolitan } \\
\text { (Beijing, China) }\end{array}$ & $\begin{array}{l}\text { System Dynamics Model System } \\
\text { of urban sustainability indicators } \\
\text { GIS (Geographic Information } \\
\text { System) }\end{array}$ & $\begin{array}{l}\text { Simulating different urban development scenarios to } \\
\text { assess their possible effects both temporally and } \\
\text { spatially. The objective is to choose the preferable } \\
\text { development strategy. }\end{array}$ \\
\hline $\begin{array}{c}\text { Pagano et al., } \\
2017\end{array}$ & $\begin{array}{c}\text { Municipal } \\
\text { (L'Aquila, Italy) }\end{array}$ & $\begin{array}{l}\text { System Dynamics Model System } \\
\text { of performance criteria }\end{array}$ & $\begin{array}{l}\text { Assessing the evolution of the resilience of a } \\
\text { drinking water supply in case of natural disaster. }\end{array}$ \\
\hline $\begin{array}{c}\text { Tan et al., 2018 } \\
\text { Metropolitan } \\
\text { (Beijing, China) }\end{array}$ & $\begin{array}{l}\text { System Dynamics Model System } \\
\text { of indicators }\end{array}$ & $\begin{array}{l}\text { Evaluating three different urban development } \\
\text { scenarios considering their possible impacts over } \\
\text { time on social, economic and environmental sectors. }\end{array}$ \\
\hline $\begin{array}{c}\text { Metropolitan } \\
\text { (Chongqing, China) }\end{array}$ & $\begin{array}{l}\text { System Dynamics Model GIS } \\
\text { Analytic hierarchy Process (AHP) } \\
\text { System of indicators and indices }\end{array}$ & $\begin{array}{l}\text { Development of an integrated evaluation model to } \\
\text { assess four different urban scenarios considering the } \\
\text { dynamic evolution of considered indicators in both } \\
\text { temporal and spatial dimensions. }\end{array}$ \\
\hline
\end{tabular}

\subsubsection{Illustrative Example}

In this section, the application of SDM developed by Tan et al. [13] to the case study of Beijing (China) is considered for the illustration of the fundamental steps of the procedure and the typology of results that the method is able to deliver. In [13], the SDM are applied to simulate the urban sustainability performance of the city, considering three different development scenarios. The SDM has been developed following these steps: (1) identifying the key variables by a review of urban sustainability indicators; (2) building the stock and flow diagram to identify the relationships between the variables; and (3) simulating different scenarios. Figure 3 shows the stock and flow diagram of the social sector. In particular, the stocks of the diagram are (1) Total population, (2) Urbanization rate, and (3) GDP, whereas all the other variables represent the flows. The diagram also shows the relationships that exist among the considered variables. As an example, we can consider the relationship that exists between "local government annual fiscal revenue" and "financial educational investment". That means the investment in educational fields strictly depends on the availability of government financial resources. It appears clear that the SDM model tries to describe the real-world functioning through its stock and flow diagram, based on real behavior.

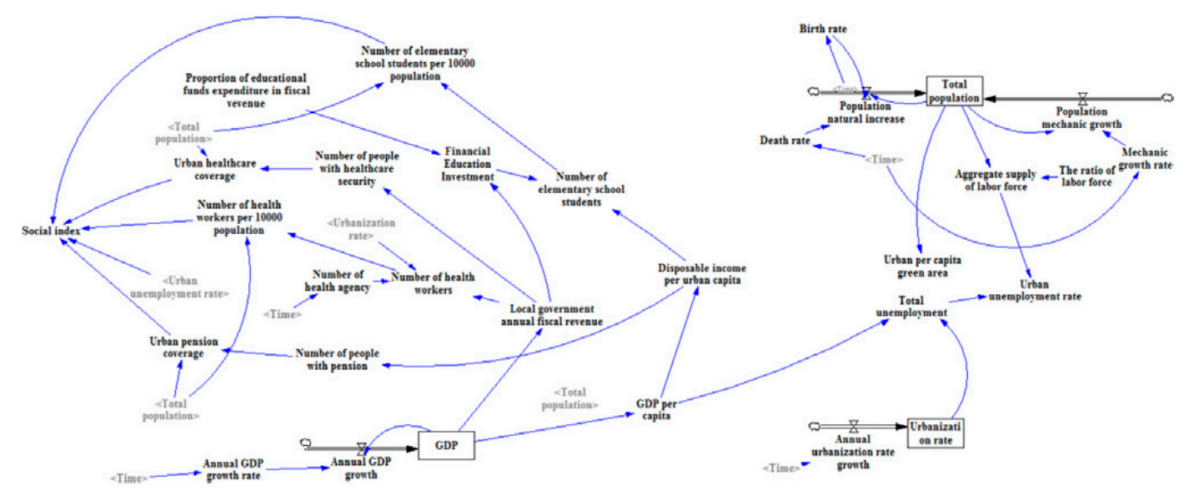

Figure 3. Stock and Flow diagram of social dimension (Source: Tan et al., 2018).

Figure 4 illustrates the results of SDM scenarios simulation, gathered by the stock and flow diagram in Figure 3.

These outcomes reveal the evolution of the indicators over time, referred to three different development scenarios (Figure 4). Simulation has been obtained by mathematical equations. For instance, Equation (2) illustrates the equation of annual household waste emission: 
where:

(1) "HWS" is the annual household's waste emission;

(2) "DSWE" is the domestic solid waste emission.

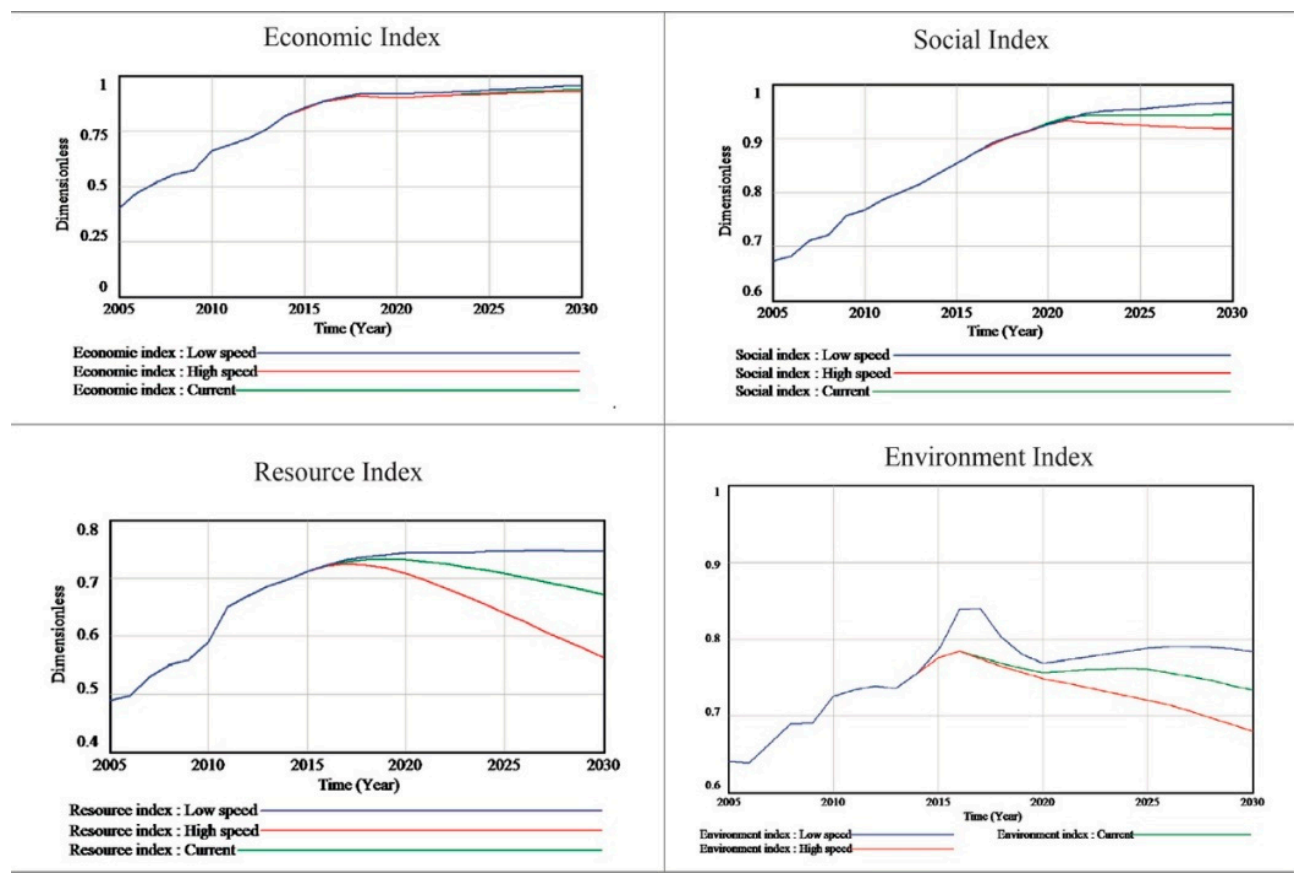

Figure 4. SDM simulation results of economic, social, resource and environmental index (Source: Tan et al., 2018).

Specifically, in Figure 5, the SDM simulation results are referred to (1) "Current scenario" which represents no change in urban development actions; (2) "High speed scenario" that is characterized by a faster urbanization process and a higher economic growth rate; and (3) "Slow scenario" in which the urbanization process is limited.

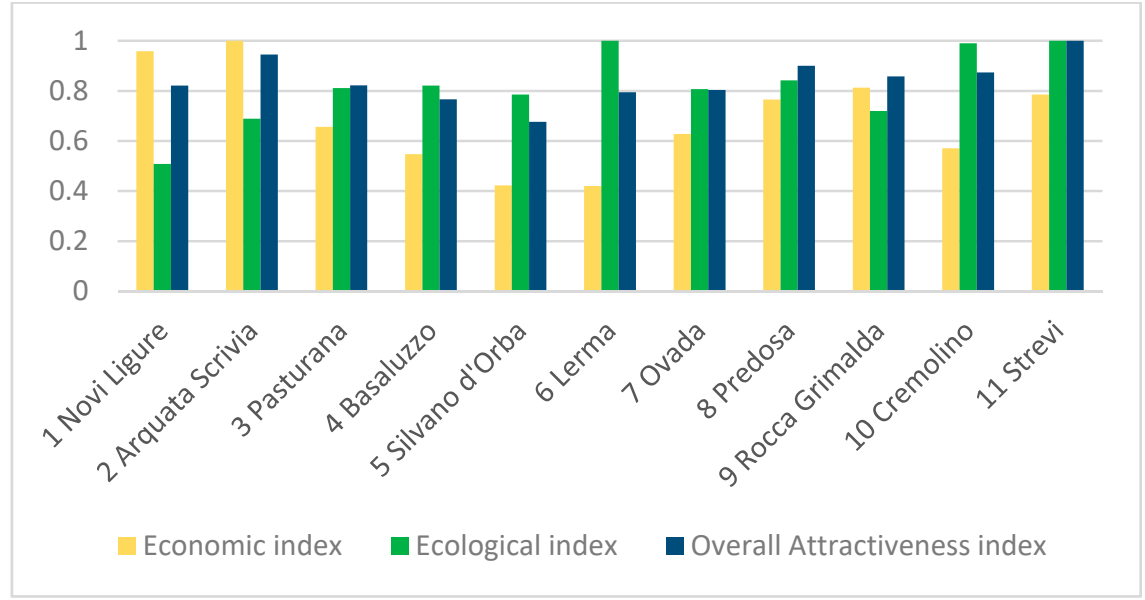

Figure 5. The histogram illustrates the ecological indices, the economic indices and the Overall Attractiveness index that were calculated for the considered 11 Clusters (Elaboration from Assumma et al., 2018). 


\subsection{Lotka-Volterra Cooperative Systems}

\subsubsection{Methodological Background and State of Art}

Lotka-Volterra models (LV) are generally employed in the field of landscape ecology for exploring the prey-predator interactions $[67,68]$. These models have been integrated only recently in wide integrated evaluation frameworks to better interpret non-linear dynamics of territories, and so, their capability to adapt themselves to natural and/or anthropic disturbances and disasters, thus going beyond the analyses of ecological systems [55].

In fact, the aim of Lotka-Volterra models within territorial and urban planning consist in being a support for the investigation of a given environmental system $\mathrm{N}$ and the prediction of possible future transformations.

As shown in Equation (3), these models assume the form of a pair of non-linear Ordinary Differential Equations (ODEs) [69]:

$$
\begin{aligned}
& p_{1}^{\prime}=a_{1} p_{1}+b_{1} p_{1}^{2}+a_{12} p_{1} p_{2}+I_{1} \\
& p_{2}^{\prime}=a_{2} p_{2}+b_{2} p_{2}^{2}+a_{21} p_{1} p_{2}+I_{2}
\end{aligned}
$$

where

$a_{1}$ and $a_{2}$ are Malthusian coefficients that consider the dynamic evolutions of the populations $p_{1}$ and $p_{2}$ in terms of natality and mortality rates;

$b_{1}$ and $b_{2}$ are Verhulst coefficients that considers scarce territorial resources, with $b_{1}, b_{2}<0$. These coefficients are proportional to carrying capacity $\left(c_{1}, c_{2}\right)$ with $b_{1}=\frac{e}{c_{1}}$ and $b_{2}=\frac{e}{c_{2}}$;

$a_{12}$ and $a_{21}$ are the terms that characterize the interaction between the two populations. In this way, we may consider three cases that correspond to three types of Lotka-Volterra models [69]:

- if $a_{12}, a_{21}>0, p_{1}$ benefits from the presence of the second state variable $p_{2}$, then Lotka-Volterra models are defined as "cooperative";

- if $a_{12}, a_{21}<0$, the first state variable competes with the second state variable, then Lotka-Volterra models are "competitive";

- if $a_{12}<0$ (prey), $a_{21}>0$ (predator), it means that the two variables are opposite, then Lotka-Volterra models are "prey/predator".

Lastly, $I_{1}$ and $I_{2}$ represent the rates of in-migration and out-migration.

Among the types of Lotka-Volterra models, this paper is focused on Lotka-Volterra cooperative type models. An example of a Lotka-Volterra cooperative type model for the state variables $V$ and $E$ is:

$$
\begin{gathered}
V^{\prime}=b(1-V) V-c V \\
E^{\prime}=d(1-E) E-f(1-V) E
\end{gathered}
$$

where

$$
\begin{array}{llll}
a_{1}=b-c & b_{1}=-b & a_{12}=0 & I_{1}=0 \\
a_{2}=d-f & b_{1}=-d & a_{21}=f & I_{2}=0
\end{array}
$$

In Table 5, a number of literature contributions are listed, in that the outcome of Lotka-Volterra systems may be interpreted as a resilience factor. More in details, Finotto and Monaco [70] and Gobattoni et al. [71,72] are generally used for developing stability analyses on ecological sectors, thus predicting future possible equilibrium states; Monaco and Servente [69] are used to simulate the population's mobility and Monaco [73] integrates a synthetic index calculated through a system of indicators for investigating the population's mobility with respect to Gross Leasable Areas (GLAs); Assumma et al. $[74,75]$ predicts the population's flow over time in rural landscapes with respect to the economic attractiveness; Assumma et al. [76] simulates the dynamics related to economic attractiveness and ecological quality as resilience factor. 
Table 5. Application of Lotka-Volterra models applied to territorial and urban planning (Authors' elaboration, 2019).

\begin{tabular}{|c|c|c|c|}
\hline \multicolumn{4}{|c|}{ Lotka-Volterra Models Applied to Territorial and Urban Planning } \\
\hline Authors and Year & $\begin{array}{l}\text { Territorial } \\
\text { Scale }\end{array}$ & Method & Outcome \\
\hline $\begin{array}{l}\text { Finotto and Monaco, } \\
\qquad 2010\end{array}$ & Municipal & $\begin{array}{l}\text { Stability analysis for predicting the } \\
\text { production and the time variation of } \\
\text { bioenergy; Analysis of territorial } \\
\text { characteristics using the ecological graph }\end{array}$ & $\begin{array}{l}\text { Identification of interventions to guarantee } \\
\text { the ecological functions of the environmental } \\
\text { system with attention on the reduction of the } \\
\text { urban sprawl. }\end{array}$ \\
\hline $\begin{array}{l}\text { Gobattoni et al., 2012, } \\
\text { 2014, 2016) }\end{array}$ & Provincial & PANDORA model & $\begin{array}{l}\text { Stability analysis on ecological equilibria as } \\
\text { future ecological scenarios. }\end{array}$ \\
\hline $\begin{array}{l}\text { Assumma, Bottero and } \\
\text { Monaco, 2016, 2019) }\end{array}$ & Sub-regional & $\begin{array}{l}\text { Lotka-Volterra models; System of } \\
\text { indicators and indices }\end{array}$ & $\begin{array}{l}\text { Simulation of the population's mobility with } \\
\text { respect to the economic attractiveness. }\end{array}$ \\
\hline $\begin{array}{l}\text { Assumma, Bottero, } \\
\text { Monaco and Soares, } 2018\end{array}$ & Supra-Municipal & $\begin{array}{l}\text { Lotka-Volterra models; System of } \\
\text { indicators and indices }\end{array}$ & $\begin{array}{l}\text { Simulation of the population's dynamics } \\
\text { related to economic attractiveness and } \\
\text { ecological states as resilience factor. }\end{array}$ \\
\hline $\begin{array}{l}\text { Monaco, } 2015 \text { Monaco } \\
\text { and Servente, } 2006\end{array}$ & Provincial & $\begin{array}{l}\text { Lotka-Volterra models; System of } \\
\text { indicators and indices }\end{array}$ & $\begin{array}{l}\text { Customer flow is intended as the } \\
\text { attractiveness expressed by a system of Gross } \\
\text { Leasable Areas (GLAs) by considering their } \\
\text { degree of accessibility. }\end{array}$ \\
\hline $\begin{array}{l}\text { Capello and Faggian, } \\
\qquad 2002\end{array}$ & Municipal & $\begin{array}{l}\text { Lotka-Volterra models of prey-predator } \\
\text { type }\end{array}$ & $\begin{array}{l}\text { Urban population, urban rent and production } \\
\text { profits are combined for understanding urban } \\
\text { dynamics of Italian cities. }\end{array}$ \\
\hline
\end{tabular}

Therefore, Lotka-Volterra models have been employed at different spatial scales with different purposes, thus obtaining useful insights, such as in the field of landscape ecology and landscape economics [77]. In this section, a recent application on a supra-municipal context in Piedmont region (Italy) is proposed [76].

\subsubsection{Illustrative Example}

In Assumma et al. [76], an extension of a Lotka-Volterra model by Monaco and Rabino [78] was developed (Equation (5)) with the aim at simulating population dynamics as a resilient factor related to ecological and economic states for the territory of the Monferrato Ovadese in Southern Piedmont (Italy). The case study under investigation was intended as a multi-pole territorial system, where the poles refer to 37 municipalities that were grouped into 11 territorial clusters.

$$
P_{\prime}{ }_{i}=A_{i} P_{i}(t)\left(1-P_{i}(t) / S_{i}\right)+\sum_{j \neq i}^{n} A_{i} / A_{j}\left[1-\left(d_{i j} / d_{M}\right)\right] P_{J}(t)
$$

where $P^{\prime}{ }_{i}$ is the state variable of the population $i ; A$ represents a synthetic index of ecological quality and economic attractiveness calculated for the poles $i$ and $j ; d_{i j}$ consists in the distance recorded between the poles $i$ and $j$, whereas $d_{M}$ measures the recorded highest distance between the poles; and $S_{i}$ is the carrying capacity, that is intended as the threshold number of people in a given pole.

It has to be noticed that the parameter $A_{\mathrm{i}}$ was calculated by considering a system of landscape economic indicators and a system of ecological indicators, according to a Multicriteria approach (for more, please see $[74,79,80])$. The considered systems of indicators and their indices aim to calculate a super-index that measures the overall attractiveness of the territory by considering the ecological quality and the economic attractiveness. The index of overall attractiveness was integrated into the Lotka-Volterra model in order to simulate the trends of populations with respect to both ecological and economic states. The results obtained by an evaluation procedure based on a Multicriteria approach are illustrated in Figure 5, whereas the results of the Lotka-Volterra model simulations are shown in Figure 6.

The results of the model are useful for predicting possible future evolutions about the mobility of resident populations. As shown in Figure 6, the first group of populations (P1-P4) behave similarly in the transitory time, with an exception for population (P1) because of a consistent degrowth. The second 
group of populations (P5-P8) behave differently; in fact, the population of the cluster of Novi Ligure (P5) is interested by a slight degrowth, the population of the cluster Lerma (P6) grows significantly and finally, populations of the clusters of Ovada and Predosa (P8 and P9) show similar growing behaviors. In this sense, the poles were intended as receptors of the considered territory that absorb and evolve toward a new state, as already said, with respect to ecological and economic aspects. The predicted scenarios on population dynamics were interpreted as the effects of the non-linear interactions between the ecological and economic components with the multi-pole territorial system. In fact, when the multi-pole territorial system shows a good equilibrium between ecological and economic aspects, the population grows significantly, as in the case of the population of the cluster of Predosa (P8); whereas when one of the considered components records negative values, the population decreases, as in the case of the population of the cluster of Novi Ligure (P1).

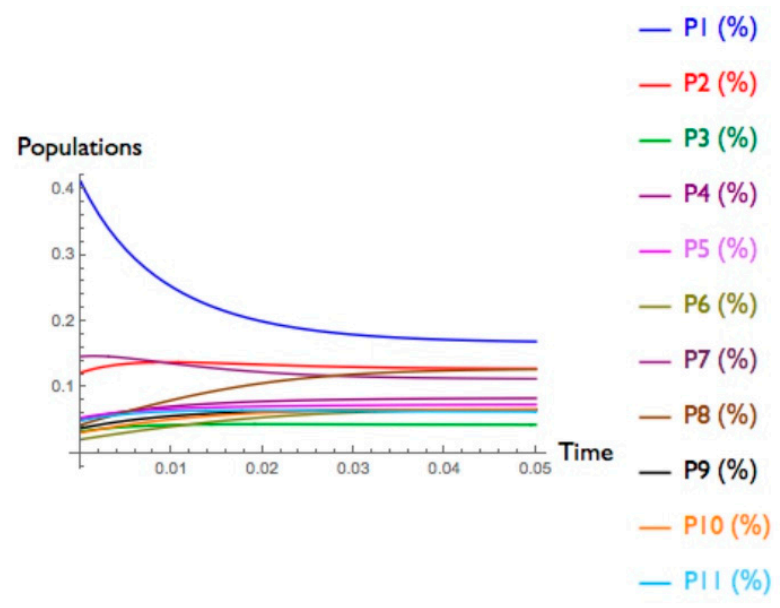

Figure 6. Future scenarios simulation of Lotka-Volterra model on population dynamics through Mathematica Software. (Assumma et al., 2018).

\section{How Can These Models Contribute for Building Resilient Systems?}

SDMs constitutes a family of tools that uses the ODEs to predict the performance of a given criterion over time and more in general cycles that depends on a number of factors, whereas the Lotka-Volterra are models that face more complex problems.

The link between the SDMs and LV models is pointed out by Crookes and Blignaut [55], who stated that prey-predator models are suitable to be used in system dynamics models [54], also finding some applications in the field of economics [81,82], ecology (see e.g., [83,84]), and in multidimensional sectors in a supply chain [85]. The most important commonality of these two methods, especially regarding to the assessment of urban resilience referred to in urban and transformation strategies, is that both the models can consider the interactions between the different elements and sectors in urban contexts. This characteristic represents the real peculiarity of these systems for evaluating urban resilience, in fact, there are no consolidated assessment methods in literature on urban resilience [86].

In this sense, a clarification about specific characteristics of SDM and LV has to be done, before the analysis of their possible contribution in decision-making for resilience enhancing. Indeed, beyond the similarity which concerns the mathematic bases, these models are quite different.

As shown in Table 6, a comparison matrix has been structured with the aim to investigate both commonalities and differences between the SDM and LV models in orienting decision problems related to urban planning, with specific attention to the resilience enhancement. 
Table 6. Lotka-Volterra models and System Dynamic Models: summarizing comparison matrix (Authors' elaboration, 2019).

\begin{tabular}{|c|c|c|c|}
\hline & & $\begin{array}{l}\text { Lotka-Volterra } \\
\text { Models }\end{array}$ & $\begin{array}{c}\text { System Dynamic } \\
\text { Models }\end{array}$ \\
\hline Nature & Essence and characters * & $\because$ & $\because$ \\
\hline \multirow{3}{*}{ Input } & Use of qualitative and quantitative data & & \\
\hline & Participatory process & & \\
\hline & Use of different spatial scales & & \\
\hline \multirow{5}{*}{ Output } & Scenario simulation & & \\
\hline & Time scale & & \\
\hline & Spatial scale & & \\
\hline & Graphical representation & & \\
\hline & Sensitivity analysis & & \\
\hline \multirow{2}{*}{ Software } & Availability & & \\
\hline & Use of Ordinary Differential Equations & & \\
\hline Integration & Integration with different techniques and methodologies & & \\
\hline \multirow{2}{*}{ Mapping } & GIS visualization & & \\
\hline & Interactivity & & \\
\hline \multirow{2}{*}{$\begin{array}{l}\text { Scenario } \\
\text { planning }\end{array}$} & Definition of objectives and strategies & & • \\
\hline & Prediction of future scenarios & $\because$ & $\because$ \\
\hline Scale & Multiscale & $\because$ & $\because$ \\
\hline
\end{tabular}

* Lotka-Volterra model is used to show the functioning of the system, whereas the System Dynamic Model is a tool used to study and analyze the model or the system.

In particular, a number of criteria have been considered for this analysis. The criteria are selected according to relevant literature review $[48,54,55]$ and to authors' researches:

- Nature highlights the different essence and characteristics of both dynamic models. On one hand, the Lotka-Volterra are models that aim to explore the dynamic functions of a given environmental system N, whereas the SDM models may be considered as a tool used to study and analyze the model or the system.

- Input is intended as the modalities to insert and deal with data at different spatial scales, as well as the possibility to integrate the participatory process. Generally, the considered dynamic models 
allow the insert of only quantitative data and the employment of different spatial scales (from local to regional and superior). As far as the participatory process is concerned in the SDM models, the decision makers may be integrated since the early phases of the process by using causal loops (Figure 1) that facilitate the interpretation of the system functioning and the integration of different stakeholders' perspectives [14,50]. In the LV models, the participatory process may be integrated only by other evaluation procedures, such as the Multicriteria Analysis (MCA), by using a system of indicators and indices [79,87].

- Output refers to the final result produced through the considered dynamic models, such as the scenario simulation, the use of the time scale, the spatial scale, the graphical representation and the sensitivity analysis with the aim to validate the scenarios produced. Particularly, both SDM and LV models simulate possible future scenarios and these represent, generally, the final output through a graphic plot in that the linear function is represented. Unlike the LV models, the SDM models show, since the initial phase, a graphical representation of the relations between the considered variables and they allow to make, after the scenario simulation, a sensitivity analysis. These two DMs use, in different ways the time scale: the SDM model use a real time scale that may be traduced in months, years or centuries, whereas the LV model uses an arbitrary time scale that may be subdivided in an initial phase when the function starts with the state of art conditions $\left(t_{0}\right)$, transitory phase, when the linear function evolves in terms of growth or degrowth, and a final phase, when the linear function became stable. The arbitrary time scale may be traduced in a real time scale by considering the historical series of the analyzed parameters [74]. Sensitivity analysis is a valuable procedure for testing the model response with respect to the variation of parameter values, as well as to identify those parameters that have more impact than the others on the investigated phenomenon [88]. Sensitivity analysis can increase the reliability of the model and thus, reduce the uncertainty of parameters used in the models. A very common sensitivity test is the One-At-Time approach (OAT) [89] that is often used in Multicriteria Analysis as final tuning $[75,90,91]$. This, in fact, facilitates the scenarios' assessment when actors and stakeholders are involved in a participatory decision-making process [92,93].

- Software refers to the availability of software and the modalities to solve the Ordinary Differential Equations (ODEs). On one hand, the SDM models are characterized by the use of specific software, such as STELLA, Venism and Powerism, that formulate themselves the ODEs from which the scenarios' simulations are produced. On the other hand, LV models are generally employed through mathematical software, such as MatLab and Mathematica Software, and these need to write manually the ODEs to obtain the prediction of scenarios (Figure 6). In this sense, both the dynamic models use the ODEs as an output, but in different ways. From the point of view of the availability, both dynamic models may be written through specific packages in open programming languages, such "deSolve" for R, "Simupy" for Python, "Mat Cont for Matlab" and "Nova modeler" for ecological modelling.

- Integration refers to the capability of DMs to integrate different techniques and evaluation methodologies. For instance, the considered dynamic models are a suitable tool to being integrated with Multicriteria Analysis (MCA) [75], as well as with the Agent-Based Models (ABM) [94] and Hedonic Price Model (HPM) [95]. Specifically, MCA can be used at two different phases: (1) at the beginning, to support the problem articulation and the identification of the variables to be included in the model; (2) after the scenarios' simulation to support the evaluation of the different performances through final score calculation or ranking elaboration. Shafiei et al. [96] integrate SDM and Agent-Based Models to better understand the effects, not only on the system but also on the agent of the transition to sustainable mobility.

- Mapping is intended as the possibility to visualize the scenarios using GIS-based methods and the possibility to interact the dynamic model and the GIS interface through a programming language (e.g., QGIS and Python). Actually, the integration of DMs simulation results into GIS is developed by users in specific plug-ins (e.g., PANDORA 3.0 [97]) or by using specific coding 
platforms (e.g., QGIS Python console) and to get a spatial visualization of the output. Despite the requirement of specific competences to manage DMs in GIS environment, the users may support decision makers in better interpreting certain dynamics related to urban resilience by visualizing spatially the output of the dynamic model in a final map and therefore, identifying specific policies and solutions.

- Scenario planning refers to the prediction of future scenarios and the definition for each scenario of objectives and strategies. Both SDM and LV models allow to predict the way variables evolve, starting from the state of art conditions $\left(\mathrm{t}_{0}\right)$ [50]. In this sense, both the SDM and the LV models are useful supports for the decision makers for identifying the most critical areas and adopting specific policies and interventions.

- Scale refers to the application of dynamic models at different scales. Moreover, the SDM considers a system as a whole, analyzing and focusing on its components and sub-components. In fact, SDMs are mostly applied to municipal or metropolitan scales. LV models are generally employed to provincial and sub-regional scales and to those territories with a rural vocation.

\section{Conclusions and Future Perspectives}

This paper explored the role of the family of dynamic models (DMs) and their characteristics as support in the decision-making process for evaluating complex phenomena, as in the case of the resilience of urban and territorial systems. Particularly, the study on the state of the art of resilience, urban resilience, dynamic models and urban simulation methods provided an epistemological contribution to the issue. The examples considered in this paper can be useful to further explore the opportunities of analysis application to investigate the key variables of issues in cities and territories. The comparison matrix highlighted commonalities, differences and potential synergies between the SDM and LV models. Both the SDM and LV models may be considered reliable supporting tools for policy planning, thanks to their ability to predict possible future behaviors of selected key variables, thus helping actors and stakeholders to identify and prioritize shared objectives and strategies for increasing urban resilience. In fact, these DMs are able to integrate the scientific knowledge available in literature within the evaluation procedure with specific expert knowledge elicited in the participatory modelling processes [98]. Some final remarks with respect to building more resilient systems [99] could be:

- These DMs are currently considered as some of the most promising models for understanding multi-dimensional problems related to urban and territorial systems.

- If experiments are impossible in the real world, simulations become the main way we can learn effectively about the dynamics of complex systems. Dynamic models are the most appropriate techniques to simulate complex and dynamic systems with the aim of developing policy and learning to effectively manage the system $[50,100]$.

- These models are able to predict the effects of the actions over time on the state of the system. For this reason, both the DMs considered can be applied to evaluate the possible effects of urban and territorial policies in order to enhance urban resilience.

- The integration of dynamic models with urban simulation methods makes it possible to support data collection and elaboration, problem structuring, and facilitate the involvement of actors and stakeholders [12,88,101-103].

The authors have applied both SDM and LV models to a common case study, of a city with more than 50,000 inhabitants, with the purpose of evaluating urban resilience performance. The aim of the authors consists in effectively testing the multi-scale by aggregating or disaggregating the data as variables of the models [103]. A set of urban development scenarios will be predicted, considering the short-, medium- and long-term period [64] and a set of objectives and strategies for enhancing urban resilience will be prioritized. From the methodological point of view, this will be developed as an interactive procedure through dynamic models that may interact with GIS software from the 
early stages of the process. Finally, an integrated tool will be developed to evaluate possible effects of natural or anthropic disasters that could compromise the resilience performance of systems, also evaluating the economic losses caused by the perturbations of the system.

Author Contributions: All authors contributed equally to the development of this paper: Conceptualization, V.A., M.B., G.D., E.D.A. and R.M.; Investigation, V.A., M.B., G.D., E.D.A. and R.M.; Validation, V.A., M.B., G.D., E.D.A. and R.M.; Writing-original draft preparation, V.A., M.B., G.D., E.D.A. and R.M.; Writing-review and editing, V.A., M.B., G.D., E.D.A. and R.M. All authors have read and agreed to the published version of the manuscript.

Funding: Part of this research has been financed by Department of Regional Studies and Planning, DIST, Politecnico di Torino within the research project titled VALIUM (Valuation for Integrated Urban Management) [grant number 60_RDI19BOM01].

Conflicts of Interest: The authors declare no conflict of interest.

\section{References}

1. Collins, A. The Global Risks Report 2019 14th Edition Insight Report. 2019. Available online: http: //www3.weforum.org/docs/WEF_Global_Risks_Report_2019.pdf (accessed on 16 December 2019).

2. Gencer, E.A.; For, A.H.; Government, L. A Handbook for Local Government Leaders Making Cities Resilient—My City is Getting Ready! Making Cities Resilient-My City is Getting Ready! UNISDR: Geneva, Switzerland, 2017.

3. Bottero, M.; Caprioli, C.; Cotella, G.; Santangelo, M. Sustainable Cities: A Reflection on Potentialities and Limits based on Existing Eco-Districts in Europe. Sustainability 2019, 11, 5794. [CrossRef]

4. Datola, G.; Bottero, M.; De Angelis, E. How Urban Resilience Can Change Cities: A System Dynamics Model Approach. In Proceedings of the Computational Science and Its Applications-ICCSA 2019; Misra, S., Gervasi, O., Murgante, B., Stankova, E., Korkhov, V., Torre, C., Rocha, A.M.A.C., Taniar, D., Apduhan, B.O., Tarantino, E., Eds.; Springer International Publishing: Cham, Germany, 2019; pp. 108-122.

5. UNISDR. The Sendai Framework for Disaster Risk Reduction: The Challenge for Science. R. Soc. Meet. Note. 2015. Available online: https://royalsociety.org/ \{\}/media/policy/Publications/2015/300715-meeting-note\%20sendai-framework.pdf (accessed on 16 December 2019).

6. United Nations. International Strategy for Disaster Reduction Hyogo Framework for Action 2005-2015: Building the Resilience of Nations. 2015. Available online: https://www.unisdr.org/files/1037_ hyogoframeworkforactionenglish.pdf (accessed on 16 December 2019).

7. Desouza, K.C.; Flanery, T.H. Designing, planning, and managing resilient cities: A conceptual framework. Cities 2013, 35, 89-99. [CrossRef]

8. Chelleri, L.; Waters, J.J.; Olazabal, M.; Minucci, G. Resilience trade-offs: Addressing multiple scales and temporal aspects of urban resilience. Environ. Urban. 2015, 27, 181-198. [CrossRef]

9. Sharifi, A.; Yamagata, Y. Resilience-Oriented Urban Planning. In Proceedings of the Lecture Notes in Energy; Springer: Berlin/Heidelberg, Germany, 2018.

10. Mushir, S. Urban Resilience Planning: A Way to Respond to Uncertainties-Current Approaches and Challenges. In Making Cities Resilient; Springer: Berlin/Heidelberg, Germany, 2019.

11. Pejic Bach, M.; Tustanovski, E.; Ip, A.W.H.; Yung, K.L.; Roblek, V. System dynamics models for the simulation of sustainable urban development: A review and analysis and the stakeholder perspective. Kybernetes 2019. [CrossRef]

12. Pagano, A.; Pluchinotta, I.; Giordano, R.; Petrangeli, A.B.; Fratino, U.; Vurro, M. Dealing with Uncertainty in Decision-Making for Drinking Water Supply Systems Exposed to Extreme Events. Water Resour. Manag. 2018, 32, 2131-2145. [CrossRef]

13. Tan, Y.; Jiao, L.; Shuai, C.; Shen, L. A system dynamics model for simulating urban sustainability performance: A China case study. J. Clean. Prod. 2018, 199, 1107-1115. [CrossRef]

14. Pluchinotta, I.; Pagano, A.; Giordano, R.; Tsoukiàs, A. A system dynamics model for supporting decision-makers in irrigation water management. J. Environ. Manag. 2018, 223, 815-824. [CrossRef]

15. Schwarz, N.; Haase, D.; Seppelt, R. Omnipresent sprawl? A review of urban simulation models with respect to urban shrinkage. Environ. Plan. B Plan. Des. 2010, 37, 265-283. [CrossRef]

16. Coutu, D.L. How resilience works. Harv. Bus. Rev. 2002, 80, 46-56.

17. Luthans, F.; Vogelgesang, G.R.; Lester, P.B. Developing the Psychological Capital of Resiliency. Hum. Resour. Dev. Rev. 2006, 5, 25-44. [CrossRef] 
18. Holling, C.S. Resilience and Stability. Annu. Rev. Ecol. Syst. 1973, 4, 1-23. [CrossRef]

19. Fiksel, J. Designing Resilient, Sustainable Systems. Environ. Sci. Technol. 2003, 37, 5330-5339. [CrossRef]

20. Hollnagel, E.; Woods, D.; Leveson, N. Resilience Engineering: Concepts and Precepts; CRC Press: Boca Raton, FL, USA, 2006.

21. Carpenter, S.; Walker, B.; Anderies, J.M.; Abel, N. From Metaphor to Measurement: Resilience of What to What? Ecosystems 2001, 4, 765-781. [CrossRef]

22. Folke, C.; Carpenter, S.; Elmqvist, T.; Gunderson, L.; Holling, C.S.; Walker, B. Resilience and sustainable development: Building adaptive capacity in a world of transformations. AMBIO 2002, 31, 437-441. [CrossRef]

23. Walker, B.; Holling, C.S.; Carpenter, S.R.; Kinzig, A. Resilience, adaptability and transformability in social-ecological systems. Ecol. Soc. 2004, 9. Available online: https://www.ecologyandsociety.org/vol9/iss2/ art5/ (accessed on 16 December 2019). [CrossRef]

24. Nelson, D.R.; Adger, W.N.; Brown, K. Adaptation to Environmental Change: Contributions of a Resilience Framework. Annu. Rev. Environ. Resour. 2007, 32, 395-419. [CrossRef]

25. Tanner, T.; Mitchell, T.; Polack, E.; Guenther, B. Urban Governance for Adaptation: Assessing Climate Change Resilience in Ten Asian Cities. IDS Work. Pap. 2009, 315, 1-47. [CrossRef]

26. Tyler, S.; Moench, M. A framework for urban climate resilience. Clim. Dev. 2012, 4, 311-326. [CrossRef]

27. Ahern, J. From fail-safe to safe-to-fail: Sustainability and resilience in the new urban world. Landsc. Urban. Plan. 2011, 100, 341-343. [CrossRef]

28. Wilkinson, C. Social-ecological resilience: Insights and issues for planning theory. Plan. Theory 2012, 11, 148-169. [CrossRef]

29. Coaffee, J. Risk, resilience, and environmentally sustainable cities. Energy Policy 2008, 36, 4633-4638. [CrossRef]

30. Cutter, L.S.; Barnes, L.; Berry, M.; Burton, C.; Evans, E.; Tate, E.; Webb, J.; Carolina, S. Community and Regional Resilience: Perspectives from Hazards, Disasters, and Emergency Management. Geography 2008, 1, 2301-2306.

31. Gaillard, J.C. Vulnerability, capacity and resilience: Perspectives for climate and development policy. J. Int. Dev. 2010, 22, 218-232. [CrossRef]

32. Meerow, S.; Newell, J.P.; Stults, M. Defining urban resilience: A review. Landsc. Urban. Plan. 2016, 147, 38-49. [CrossRef]

33. Godschalk, D.R. Urban Hazard Mitigation: Creating Resilient Cities. Nat. Hazards Rev. 2003, 4, $136-143$. [CrossRef]

34. Batty, M. The size, scale, and shape of cities. Science. 2008, 319, 769-771. [CrossRef]

35. Klein, R.J.T.; Nicholls, R.J.; Thomalla, F. Resilience to natural hazards: How useful is this concept? Environ. Hazards 2003, 5, 35-45. [CrossRef]

36. Adger, W.N. Social and ecological resilience: Are they related? Prog. Hum. Geogr. 2000, 24, 347-364. [CrossRef]

37. Pendall, R.; Foster, K.A.; Cowell, M. Resilience and regions: Building understanding of the metaphor. Cambr. J. Reg. Econ. Soc. 2010, 3, 71-84. [CrossRef]

38. Sharifi, A.; Yamagata, Y. Principles and criteria for assessing urban energy resilience: A literature review. Renew. Sustain. Energy Rev. 2016, 60, 1654-1677. [CrossRef]

39. Leichenko, R. Climate change and urban resilience. Curr. Opin. Environ. Sustain. 2011, 3, 164-168. [CrossRef]

40. Pierce, J.C.; Budd, W.W.; Lovrich, N.P. Resilience and sustainability in US urban areas. Environ. Politic 2011, 20, 566-584. [CrossRef]

41. Sharifi, A.; Yamagata, Y. Major Principles and Criteria for Development of an Urban Resilience Assessment Index. In Proceedings of the International Conference and Utility Exhibition on Green Energy for Sustainable Development (ICUE), Pattaya City, Thailand, 19-21 March 2014; pp. 1-5.

42. Holling, C.S. Resilience and Stability of Ecological Systems. Annu. Rev. Ecol. Syst. 2003, 4, 1-23. [CrossRef]

43. Cutter, S.L.; Barnes, L.; Berry, M.; Burton, C.; Evans, E.; Tate, E.; Webb, J. A place-based model for understanding community resilience to natural disasters. Glob. Environ. Chang. 2008, 18, 598-606. [CrossRef]

44. Tompkins, E.L.; Amundsen, H. Perceptions of the effectiveness of the United Nations Framework Convention on Climate Change in advancing national action on climate change. Environ. Sci. Policy 2008, 11, 1-3. [CrossRef] 
45. Wang, L.; Xue, X.; Zhang, Y.; Luo, X. Exploring the Emerging Evolution Trends of Urban Resilience Research by Scientometric Analysis. Int. J. Environ. Res. Public Health 2018, 10, 2181. [CrossRef]

46. Pizzo, B. Problematizing resilience: Implications for planning theory and practice. Cities 2015, 43, $133-140$. [CrossRef]

47. Letcher, R.A.K.; Jakeman, A.J.; Barreteau, O.; Borsuk, M.E.; ElSawah, S.; Hamilton, S.H.; Henriksen, H.J.; Kuikka, S.; Maier, H.R.; Rizzoli, A.E.; et al. Selecting among five common modelling approaches for integrated environmental assessment and management. Environ. Model. Softw. 2013, 47, 159-181.

48. Neuwirth, C.; Peck, A.; Simonović, S.P. Modeling structural change in spatial system dynamics: A Daisyworld example. Environ. Model. Softw. 2015, 47, 159-181. [CrossRef]

49. Bala, B.K.; Arshad, F.M.; Noh, K.M. System Dynamics. Modelling and Simulation; Springer: Singapore, 2017; ISBN 978-981-10-2043-8.

50. Forrester, J.W. Industrial Dynamics; M.I.T. Press: Cambridge, MA, USA, 1964.

51. Forrester, J.W. Principles of Systems; System Dynamics Series; Productivity Press: Portland, OR, USA, 1990; ISBN 9780915299874.

52. Thompson, B.P.; Bank, L.C. Use of system dynamics as a decision-making tool in building design and operation. Build. Environ. 2010, 45, 1006-1015. [CrossRef]

53. Swart, J. A system dynamics approach to predator-prey modeling. Syst. Dyn. Rev. 1990, 6, 94-99. [CrossRef]

54. Crookes, D.; Blignaut, J. Predator-prey analysis using system dynamics: An application to the steel industry. S. Afr. J. Econ. Manag. Sci. 2016, 19, 733-746. [CrossRef]

55. Guan, D.; Gao, W.; Su, W.; Li, H.; Hokao, K. Modeling and dynamic assessment of urban economy-resource-environment system with a coupled system dynamics-Geographic information system model. Ecol. Indic. 2011, 11, 1333-1344. [CrossRef]

56. Güneralp, B.; Seto, K.C. Environmental impacts of urban growth from an integrated dynamic perspective: A case study of Shenzhen, South China. Glob. Environ. Chang. 2008, 18, 720-735. [CrossRef]

57. Yao, H.; Shen, L.; Tan, Y.; Hao, J. Simulating the impacts of policy scenarios on the sustainability performance of infrastructure projects. Autom. Constr. 2011, 20, 1060-1069. [CrossRef]

58. Yuan, H.; Chini, A.R.; Lu, Y.; Shen, L. A dynamic model for assessing the effects of management strategies on the reduction of construction and demolition waste. Waste Manag. 2012, 32, 521-531. [CrossRef]

59. Blumberga, A. System Dynamics for Environmental Engineering Students; Riga Technical University: Rīga, Latvia, 2011; ISBN 9789934819629.

60. Egilmez, G.; Tatari, O. A dynamic modeling approach to highway sustainability: Strategies to reduce overall impact. Transp. Res. Part A Policy Pract. 2012, 46, 1086-1096. [CrossRef]

61. Shepherd, S.P. A review of system dynamics models applied in transportation. Transportmetrica B 2014, 2, 83-105. [CrossRef]

62. Yu, C.; Chen, C.; Lin, C.; Liaw, S. Development of a system dynamics model for sustainable land use management. J. Chin. Inst. Eng. 2003, 26, 607-618. [CrossRef]

63. Park, M.; Kim, Y.; Lee, H.S.; Han, S.; Hwang, S.; Choi, M.J. Modeling the dynamics of urban development project: Focusing on self-sufficient city development. Math. Comput. Model. 2013, 57, 2082-2093. [CrossRef]

64. Wu, D.; Ning, S. Dynamic assessment of urban economy-environment-energy system using system dynamics model: A case study in Beijing. Environ. Res. 2018, 164, 70-84. [CrossRef]

65. Kunc, M.; Mortenson, M.J.; Vidgen, R. A computational literature review of the field of System Dynamics from 1974 to 2017. J. Simul. 2018, 12, 115-127. [CrossRef]

66. Lotka, A.J. Contribution to the Energetics of Evolution. Proc. Natl. Acad. Sci. USA 2006, 8, 1747. [CrossRef]

67. Turner, M.G.; Gardner, R.H. Landscape Ecology in Theory and Practice; Springer: New York, NY, USA, 2015; ISBN 978-1-4939-2793-7.

68. Monaco, R. Introduzione ai Modelli Matematici Nelle Scienze Territoriali/Roberto Monaco, Giorgia Servente; Quaderni di matematica per le scienze applicate 2; Celid: Torino, Italy, 2011; ISBN 978-88-7661-927-4.

69. Finotto, F.; Monaco, R.; Servente, G. Un modello per la valutazione di energia biologica in un sistema ambientale. Sci. Reg. 2010, 9, 61-84.

70. Pelorosso, R.; Gobattoni, F.; Menconi, M.E.; Vizzari, M.; Grohmann, D.; Ripa, M.; Leone, A. Landscape development scenario analysis by PANDORA model: An application in Umbria Region (Italy). In Proceedings of the International Conference of Agricultural Engineering CIGR-AgEng2012: Agriculture and Engineering for a Healthier Life, Valencia, Spain, 8-12 July 2012. CIGR-AgEng. 
71. Gobattoni, F.; Groppi, M.; Monaco, R.; Pelorosso, R. New Developments and Results for Mathematical Models in Environment Evaluations. Acta Appl. Math. 2014, 132, 321-331. [CrossRef]

72. Monaco, R. A mathematical model for territorial integrated evaluation. In Smart Evaluation and Integrated Design in Regional Development; Brunetta, G., Ed.; Ashgate: Farnham, UK, 2015; pp. 97-106, ISBN 9781472445834.

73. Assumma, V.; Bottero, M.; Monaco, R. Landscape Economic Value for Territorial Scenarios of Change: An Application for the Unesco Site of Langhe, Roero and Monferrato. Procedia Soc. Behav. Sci. 2016, 223, 549-554. [CrossRef]

74. Assumma, V.; Bottero, M.; Monaco, R. Landscape Economic Attractiveness: An Integrated Methodology for Exploring the Rural Landscapes in Piedmont (Italy). Land 2019, 8, 105. [CrossRef]

75. Assumma, V.; Bottero, M.; Monaco, R.; Soares, A.J. An integrated evaluation model for shaping future resilient scenarios in multi-pole territorial systems. Environ. Territ. Model. Plan. Des. 2018, 4, 17-24.

76. Assumma, V.; Bottero, M.; Monaco, R.; Soares, A.J. An integrated evaluation methodology to measure ecological and economic landscape states for territorial transformation scenarios: An application in Piedmont (Italy). Ecol. Indic. 2019, 105, 156-165. [CrossRef]

77. Monaco, R.; Rabino, G.A. A Stochastic Treatment of a Dynamic Model for an Interacting Cities System. In Mathematical Modelling in Science and Technology; Elsevier: Amsterdam, The Netherlands, 1984.

78. Bottero, M. Assessing the economic aspects of landscape. In Landscape Indicators: Assessing and Monitoring Landscape Quality; Springer: Dordrecht, The Netherlands, 2011; pp. 167-192, ISBN 9789400703650.

79. Brunetta, G.; Salizzoni, E.; Bottero, M.; Monaco, R.; Assumma, V. Measuring resilience for territorial enhancement: An experimentation in Trentino. Valori e Valutazioni 2018, 20, 69-78.

80. Goodwin, R.M. A Growth Cycle. In Essays in Economic Dynamics; Palgrave Macmillan: London, UK, 1982; pp. 165-170, ISBN 978-1-349-05504-3.

81. Weber, L. A Contribution to Goodwin's Growth Cycle Model from a System Dynamics Perspective. In Proceedings of the 23rd International System Dynamics Conference, Boston, MA, USA, 17-23 July 2005; pp. 17-21.

82. Hannon, B.; Ruth, M. Modeling Dynamic Biological Systems. In Modeling Dynamic Biological Systems; Springer: Berlin/Heidelberg, Germany, 2014; pp. 3-28, ISBN 978-3-319-05614-2.

83. Ford, F.A. Modeling the Environment: An Introduction to System Dynamics Models of Environmental Systems; Environmental Studies; Island Press: Washington, DC, USA, 1999; ISBN 9781559636001.

84. Dalimov, R.; Gappar, N. Limit Cycle, Trophic Function and the Dynamics of Intersectoral Interaction. Curr. Res. J. Econ. Theory 2010, 2, 32-40.

85. Ilmola, L. Approaches to Measurement of Urban Resilience. In Urban Resilience; Springer: Berlin/Heidelberg, Germany, 2016.

86. Saaty, T.L. The Analytic Hierarchy Process; McGraw Hill: New York, NY, USA, 1980; ISBN 0070543712.

87. Elsawah, S.; Pierce, S.A.; Hamilton, S.H.; van Delden, H.; Haase, D.; Elmahdi, A.; Jakeman, A.J. An overview of the system dynamics process for integrated modelling of socio-ecological systems: Lessons on good modelling practice from five case studies. Environ. Model. Softw. 2017, 93, 127-145. [CrossRef]

88. Norton, J. An introduction to sensitivity assessment of simulation models. Environ. Model. Softw. 2015, 69, 166-174. [CrossRef]

89. Bottero, M.; Ferretti, V.; Mondini, G. Calculating composite indicators for sustainability. In The Lecture Notes in Computer Science; Springer: Cham, Switzerland, 2015; pp. 20-35.

90. Bottero, M.; Datola, G.; Monaco, R. Exploring the resilience of urban systems using fuzzy cognitive maps. In International Conference on Computational Science and Its Applications; Springer: Berlin/Heidelberg, Germany, 2017; pp. 338-353.

91. Sušnik, J.; Vamvakeridou-Lyroudia, L.; Savic, D.; Kapelan, Z. Integrated System Dynamics Modelling for water scarcity assessment: Case study of the Kairouan region. Sci. Total Environ. 2012, 440, 290-306. [CrossRef]

92. Becchio, C.; Bottero, M.; Corgnati, S.; Dell'Anna, F. Decision making for sustainable urban energy planning: An integrated evaluation framework of alternative solutions for a NZED (Net Zero-Energy District) in Turin. Land Use Policy 2018, 78, 803-817. [CrossRef] 
93. Caprioli, C.; Bottero, M.; Pellegrini, M. An Agent-Based Model (ABM) for the Evaluation of Energy Redevelopment Interventions at District Scale: An Application for the San Salvario Neighborhood in Turin (Italy). In International Conference on Computational Science and Its Applications; Springer: Berlin/Heidelberg, Germany, 2019; ISBN 9783030243012.

94. Dell'Anna, F.; Bravi, M.; Marmolejo-Duarte, C.; Bottero, M.C.; Chen, A. EPC Green Premium in Two Different European Climate Zones: A Comparative Study between Barcelona and Turin. Sustainability 2019, 11, 5605. [CrossRef]

95. Shafiei, E.; Stefansson, H.; Asgeirsson, E.I.; Davidsdottir, B.; Raberto, M. Integrated Agent-based and System Dynamics Modelling for Simulation of Sustainable Mobility. Transp. Rev. 2013, 33, 44-70. [CrossRef]

96. Pelorosso, R.; Gobattoni, F.; Geri, F.; Leone, A. PANDORA 3.0 plugin: A new biodiversity ecosystem service assessment tool for urban green infrastructure connectivity planning. Ecosyst. Serv. 2017, 26, 476-482. [CrossRef]

97. Giordano, G.; Altafini, C. Qualitative and quantitative responses to press perturbations in ecological networks. Sci. Rep. 2017, 7, 11378. [CrossRef]

98. Elmqvist, T.; Andersson, E.; Frantzeskaki, N.; McPhearson, T.; Gaffney, O.; Takeuchi, K.; Folke, C. Sustainability and resilience for transformation in the urban century. Nat. Sustain. 2019, 2, 267-273. [CrossRef]

99. Jakeman, A.J.; Letcher, R.A.; Norton, J.P. Ten iterative steps in development and evaluation of environmental models. Environ. Model. Softw. 2006, 21, 602-614. [CrossRef]

100. Luna-Reyes, L.F.; Andersen, D.L. Collecting and analyzing qualitative data for system dynamics: Methods and models. Syst. Dyn. Rev. 2003, 19, 271-296. [CrossRef]

101. Lane, D.C. Formal theory building for the avalanche game: Explaining counter-intuitive behavior of a complex system using geometrical and human behavioural/physiological effects. Syst. Res. Behav. Sci. 2008, 25, 521-542. [CrossRef]

102. Hovmand, P.F.; Andersen, D.; Rouwette, E.; Richardson, G.; Rux, K.; Calhoun, A. Group Model-Building 'Scripts' as a Collaborative Planning Tool. Syst. Res. Behav. Sci. 2012, 29, 179-193. [CrossRef]

103. Assumma, V.; Bottero, M.; Datola, G.; Angelis, E.; Monaco, R. Come esplorare la resilienza nei sistemi urbani e territoriali? Una panoramica sui modelli dinamici (How to explore resilience in urban and territorial systems? An overview on dynamic models). In Proceedings of the 40th AISRE Conference, Beyond the crises: Renewal, Reconstruction and Local Development, L'Aquila, Italy, 16-18 September 2019, in press. 